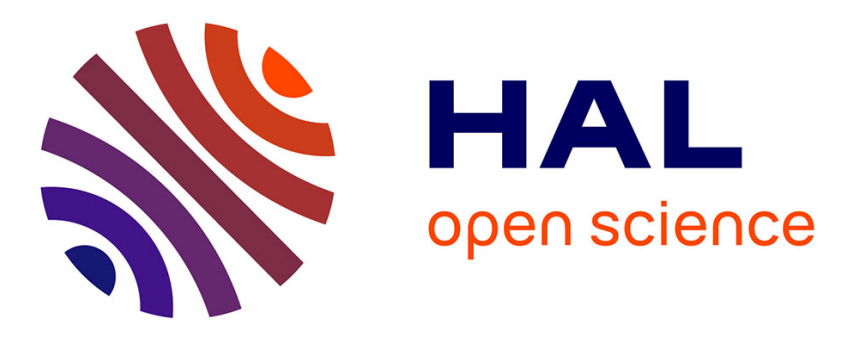

\title{
Investigation of lab and pilot scale electric-pulse fragmentation systems for the recycling of ultra-high performance fibre-reinforced concrete
}

Kathy Bru, Solène Touzé, Pascal Auger, Svatopluk Dobrusky, Jérôme Tierrie, Daniel Parvaz

\section{To cite this version:}

Kathy Bru, Solène Touzé, Pascal Auger, Svatopluk Dobrusky, Jérôme Tierrie, et al.. Investigation of lab and pilot scale electric-pulse fragmentation systems for the recycling of ultrahigh performance fibre-reinforced concrete. Minerals Engineering, 2018, 128, pp.187 - 194.

10.1016/j.mineng.2018.08.040 . hal-01869359

\section{HAL Id: hal-01869359 \\ https://hal-brgm.archives-ouvertes.fr/hal-01869359}

Submitted on 6 Sep 2018

HAL is a multi-disciplinary open access archive for the deposit and dissemination of scientific research documents, whether they are published or not. The documents may come from teaching and research institutions in France or abroad, or from public or private research centers.
L'archive ouverte pluridisciplinaire HAL, est destinée au dépôt et à la diffusion de documents scientifiques de niveau recherche, publiés ou non, émanant des établissements d'enseignement et de recherche français ou étrangers, des laboratoires publics ou privés. 


\section{Investigation of lab and pilot scale electric-pulse fragmentation systems for the recycling of ultra-high performance fibre-reinforced concrete}

Kathy $\operatorname{Bru}^{\mathrm{a}}$ *

k.bru@brgm.fr

Solène Touzéa

Pascal Auger ${ }^{\mathrm{b}}$

Svatopluk Dobrusk

Jérôme Tierrie

Daniel B.

a BRGM, Water, Environment and Ecotechnologies Division - Waste and Raw Materials \& Recycling Unit, F-45060 Orléans, France

bBRGM, Laboratories Division - Multi-scale Tests and Processes Unit, F-45060 Orléans, France

'LafargeHolcim R\&D Center, 95 rue du Montmuriel, 38291 Saint-Quentin Fallavier, France

dSELFRAG AG, Biberenzelgli 18, 3210 Kerzers, Switzerland

${ }^{*}$ Corresponding author

Abstract

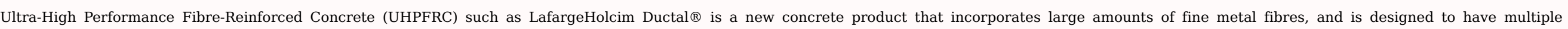

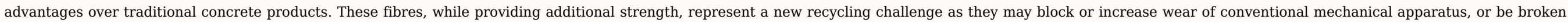

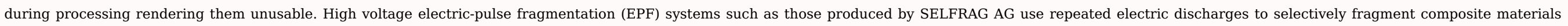

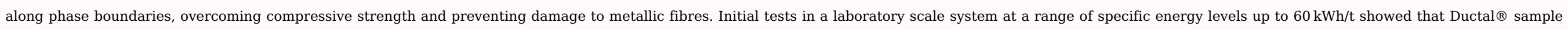

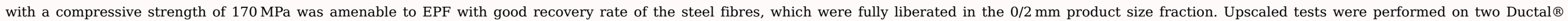

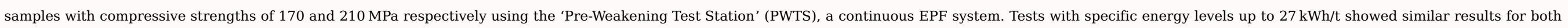

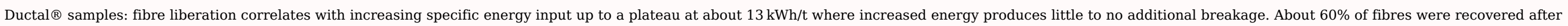

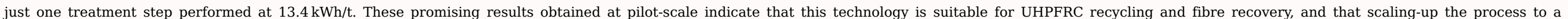
commercial level is technically feasible.

Keywords: Recycling; Ultra-high performance fibre-reinforced concrete; Electric-pulse fragmentation; Selective fragmentation

\section{Introduction}

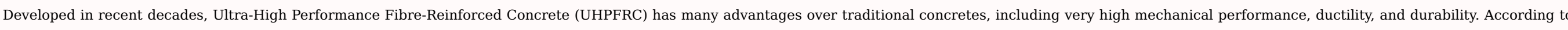

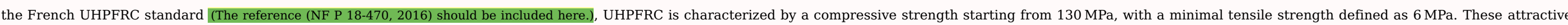
characteristics have enabled architects and engineers to build remarkable structures such as bridges, stadiums, and architectural façades.

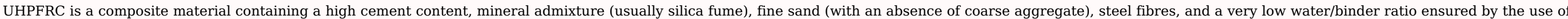




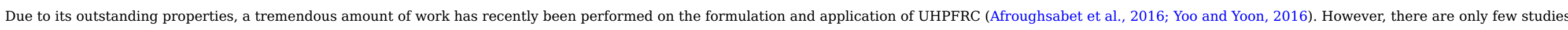

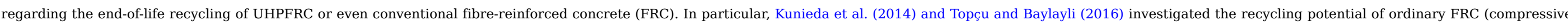

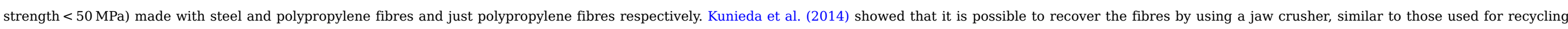

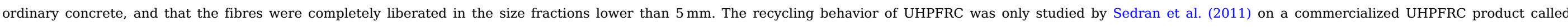

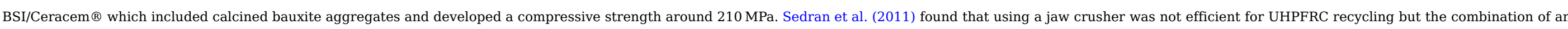
impactor and a gyratory crusher allowed liberating fibres in the size fraction $0 / 3 \mathrm{~mm}$, which could then be extracted with a magnet.

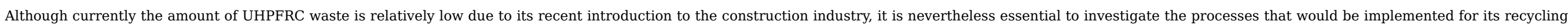

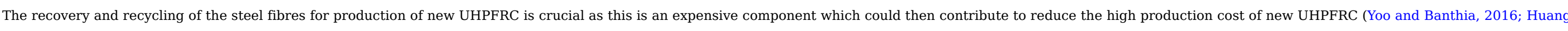

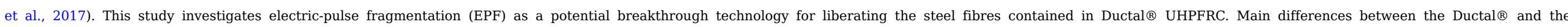
BSI/Ceracem ${ }^{\circledR}$ UHPFRC are the following (Maten, 2011):

(i) Possible heat treatment during hydration, especially applied to Ductal $\circledast$, in order to reduce creep and shrinkage deformations.

(ii) Maximum aggregate size : while Ductal $\circledast$ materials only contain very fine sand $(<1 \mathrm{~mm})$, Ceracem $\circledast$ includes up to $7 \mathrm{~mm}$-sized ultra-hard aggregate (but at a rather low content).

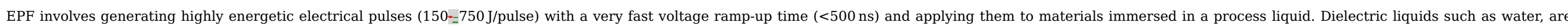

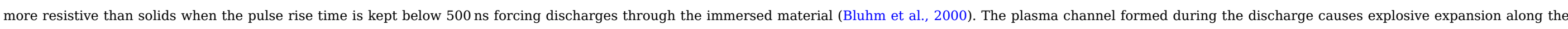
discharge pathway (electrodynamic fragmentation), and the collapse of the plasma channel produces a shock-wave that propagates through the material (electrohydraulic fragmentation).

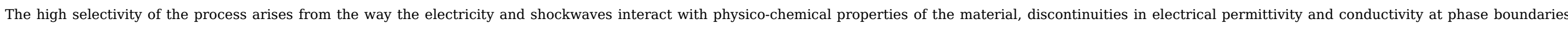

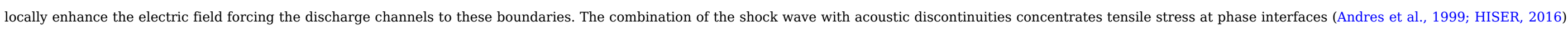
The concentration of energy and stress at phase boundaries causes selective breakage, and allows full liberation of components from the feed material.

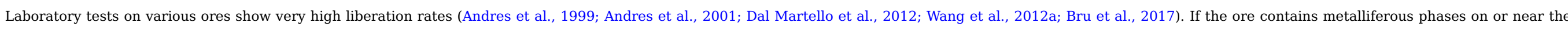

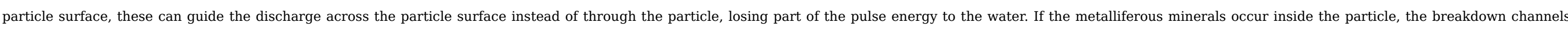

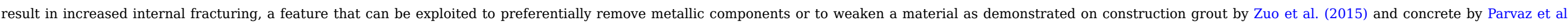

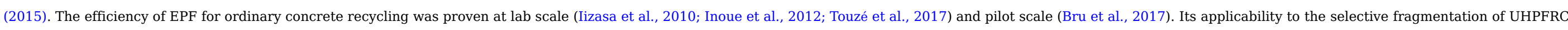
waste has not yet been studied but since it contains metallic fibres in a mineral gangue then promising results are expected.

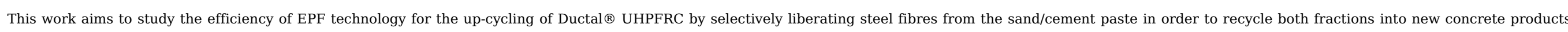

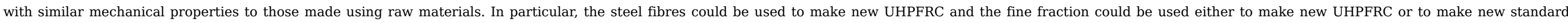
concrete.

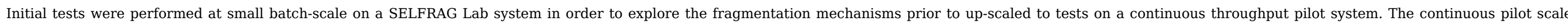

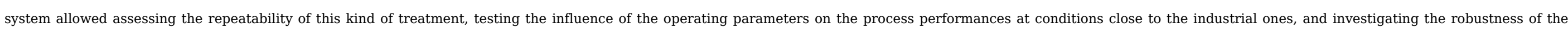
technology when treating two types of UHPFRC materials.

\section{Materials and methods}

2.1 UHPFRC samples 


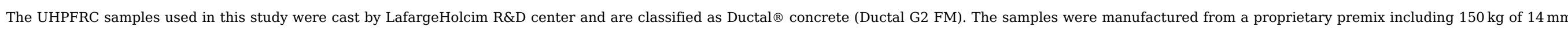

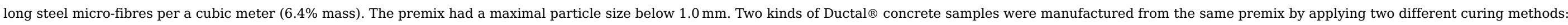

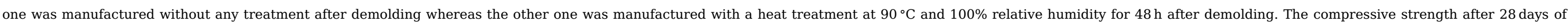

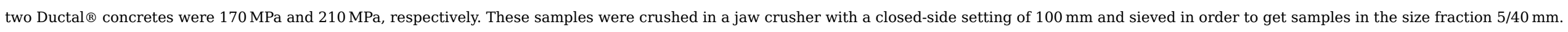

\subsection{Experimental set-up for lab scale tests}

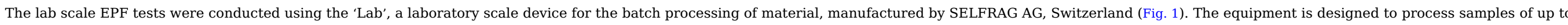

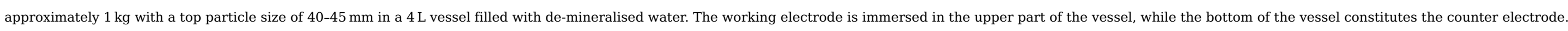

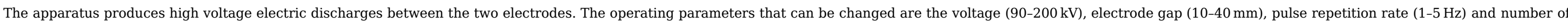
electric pulses (1-1000).

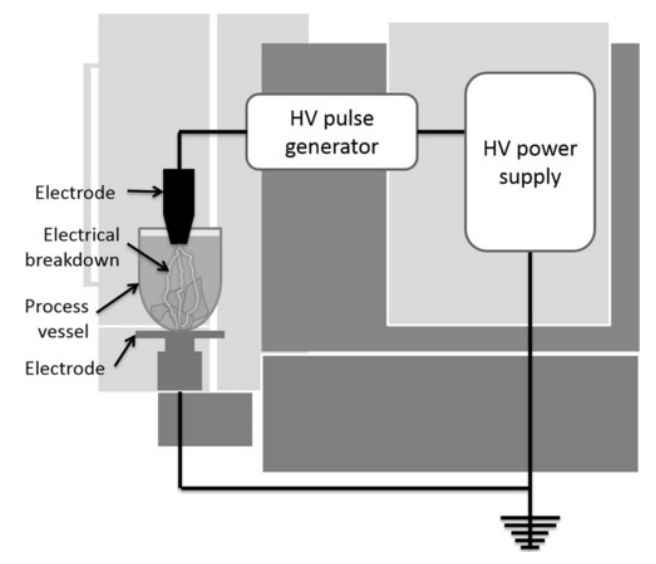

Fig. 1 Schematic of the SELFRAG Lab machine.

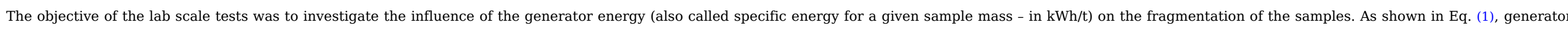

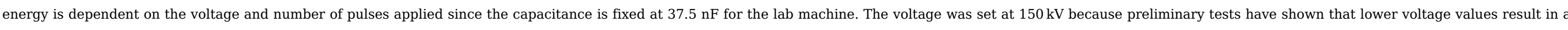

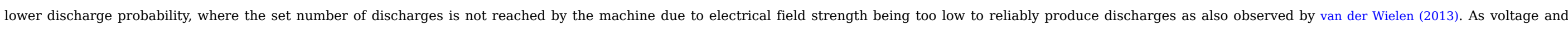
capacitance were fixed, generator energy was modified by adjusting the number of pulses.

$\mathrm{E}_{\text {gen }}=\mathrm{n} 0.5 \mathrm{CU}^{2}$

where $E_{\text {gen }}$ represents generator energy $(J), n$ is number of pulses, $C$ is capacitance $(F)$ and $U$ is pulse voltage (V).

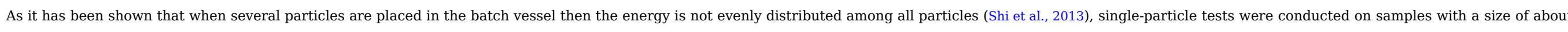
$40 \mathrm{~mm}$.

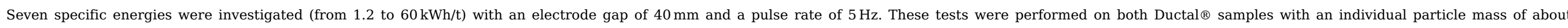
100-200 g.

\subsection{Experimental set-up for continuous pilot scale tests}

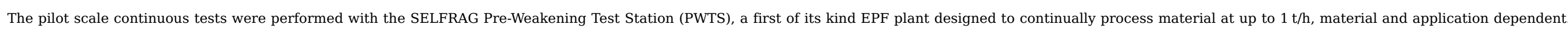

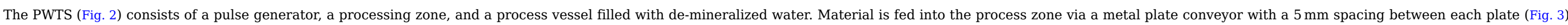




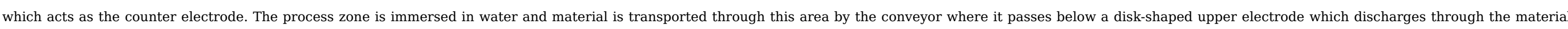

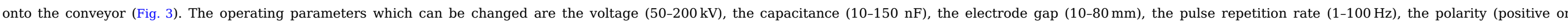

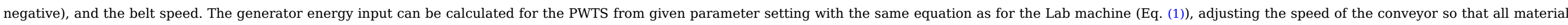
receives a comparable number of discharges.

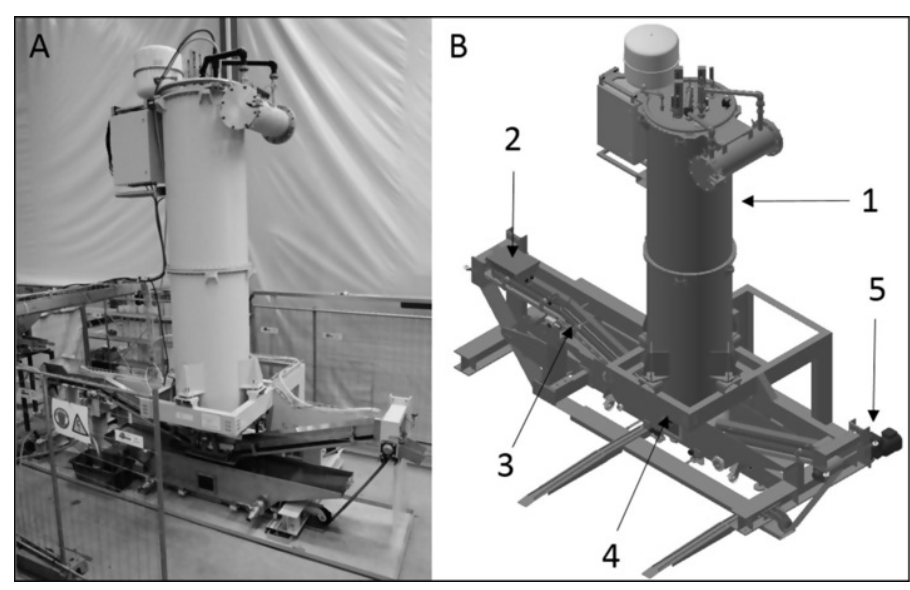

Fig. 2 A: The SELFRAG PWTS; B: 1: High voltage pulse generator; 2: feed in hopper; 3: conveyor belt; 4: process zone; 5: feed out.

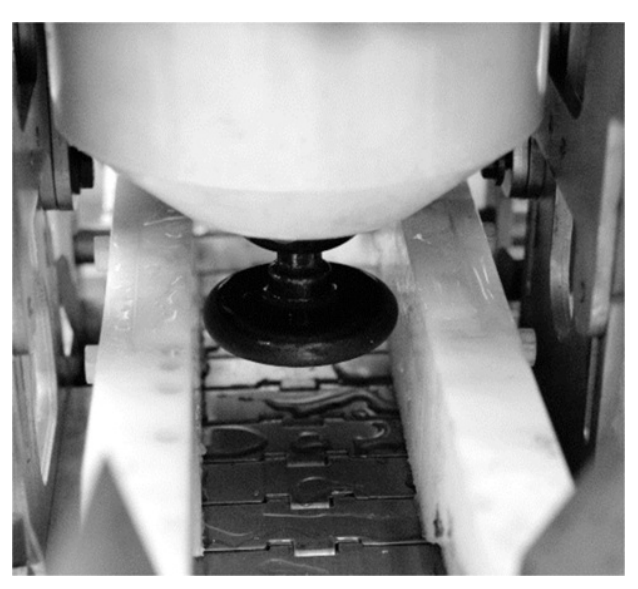

Fig. 3 PWTS process zone.

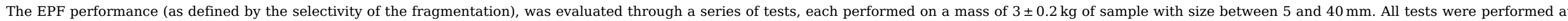

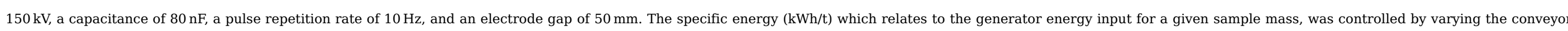

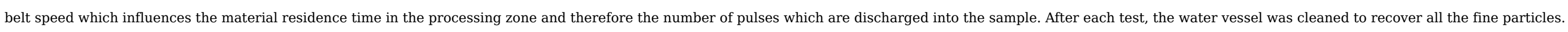

Three test series were performed:

- The first series aimed to assess the repeatability of the PWTS. Tests were carried out at a specific energy of $5 \mathrm{kWh} / \mathrm{t}$ on Ductal@ sample with a compressive strength of $170 \mathrm{MPa}$. Four replicates were performed.

- The second series aimed to study the influence of the specific energy. Tests were performed on Ductal $\circledast$ sample with a compressive strength of $170 \mathrm{MPa}$ at a specific energy of 1.1, 5.0, 13.4 and $27.5 \mathrm{kWh} / \mathrm{t}$. 


\subsection{Characterization methods}

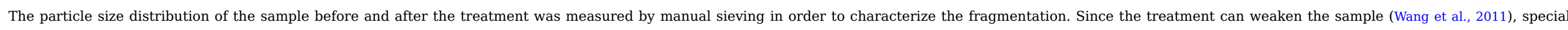

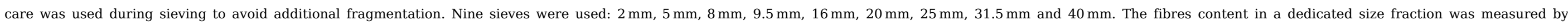
performing a magnetic separation manually.

\section{Results and discussion}

\subsection{Characteristics of the liberated steel fibres}

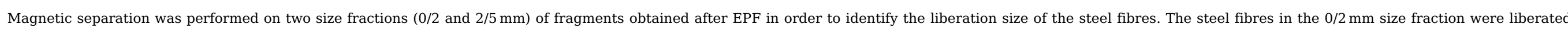

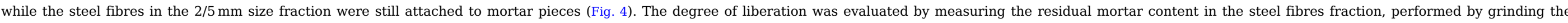

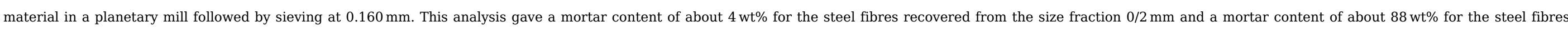

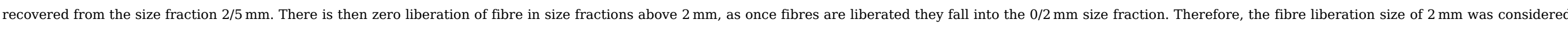

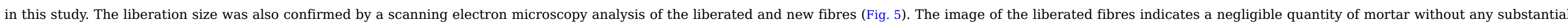
deterioration of the fibre surface.

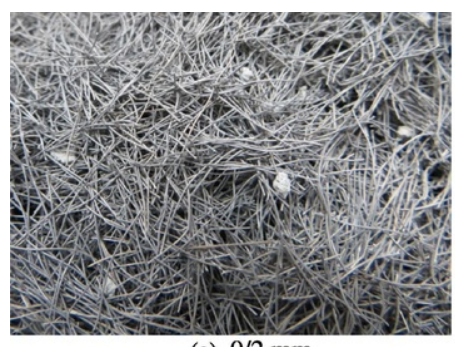

(a) $0 / 2 \mathrm{~mm}$

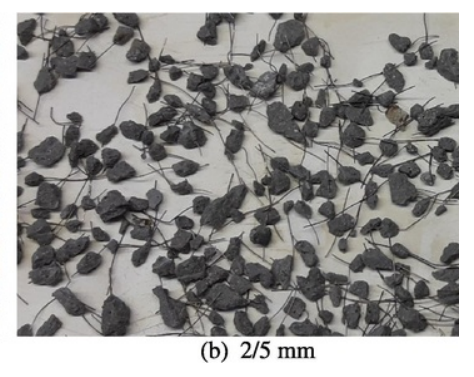

(b) $2 / 5 \mathrm{~mm}$

Fig. 4 Steel fibres contained in the size fractions 0/2 mm (a) and 2/5 mm (b) obtained after PWTS(It is possible to replace "PWTS" by "an EPF continuous treatment performed"?) treatment at $5.0 \mathrm{kWh} / \mathrm{t}$ of Ductal $@$ samples @ 170 MPa.

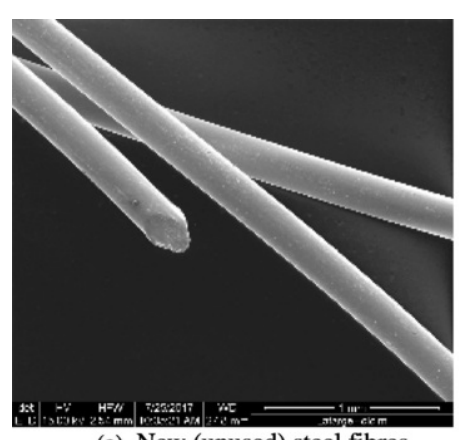

(a) New (unused) steel fibres

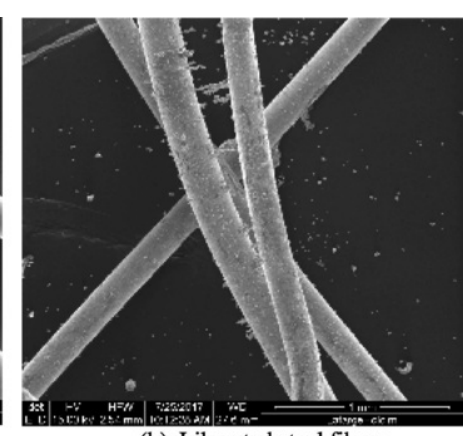

(b) Liberated steel fibres

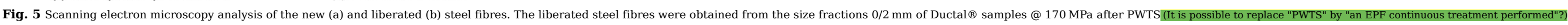
treatment at $5.0 \mathrm{kWh} / \mathrm{t}$.

\subsection{Influence of the specific energy on the fragmentation with the batch equipment}

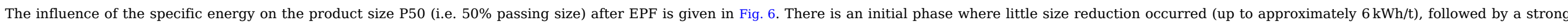




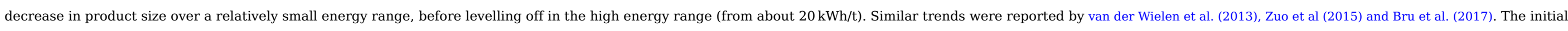

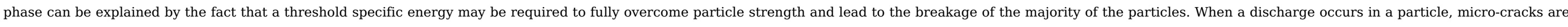

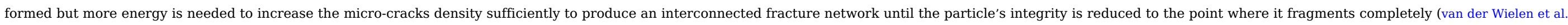

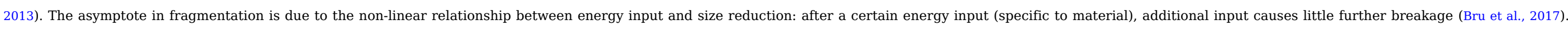

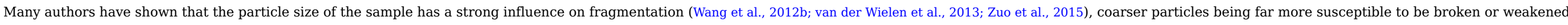

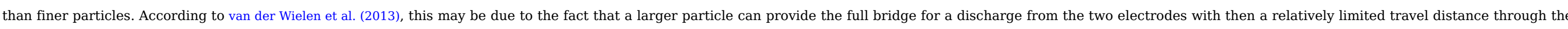

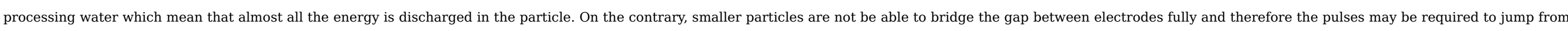
particle to particle several times, involving a longer total travel distance through water and then a larger portion of energy lost in the water and not available for fragmentation.

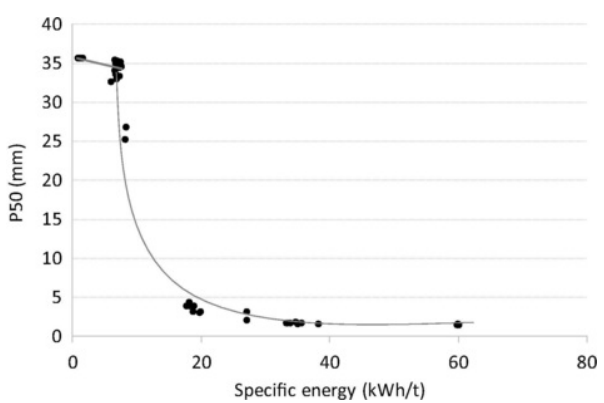

Fig. 6 Product size P50 as a function of the specific energy after batch treatment of Ductal@ samples @ 170 MPa.

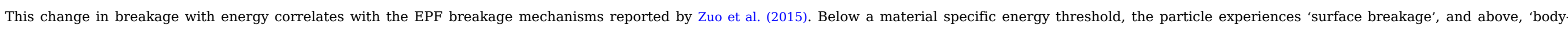

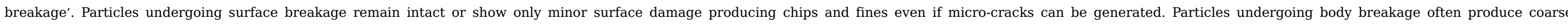

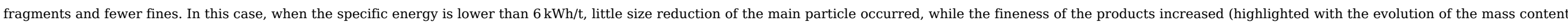

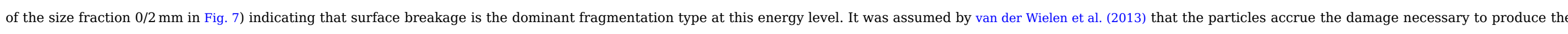

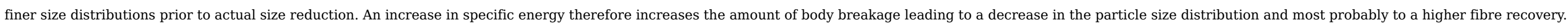

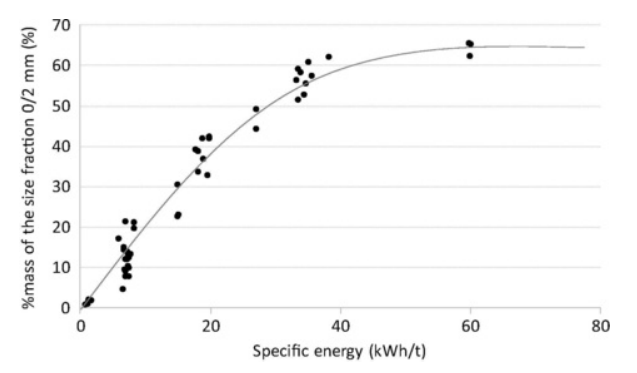

Fig. 7 Mass content of the size fraction 0/2 mm as a function of the specific energy after batch treatment of Ductal $₫$ samples @ $170 \mathrm{MPa}$

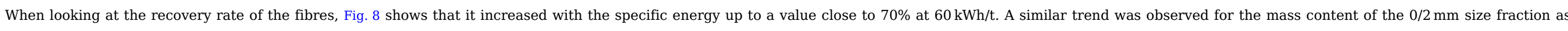

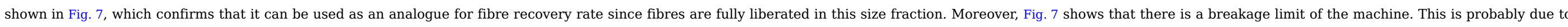

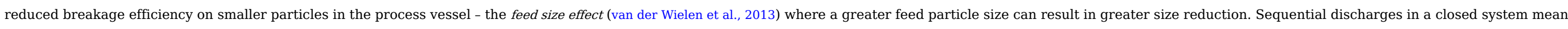
that with every discharge the 'feed' size decreases. 


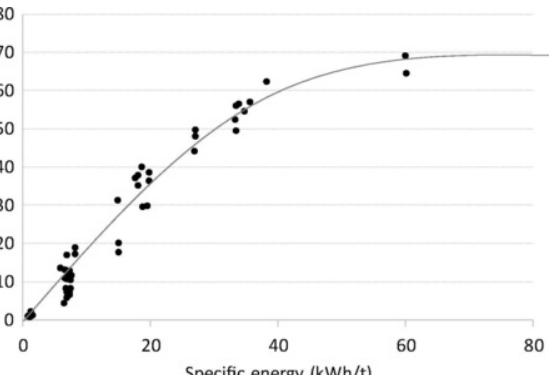

Fig. 8 Recovery rate of the fibres as a function of the specific energy after batch treatment of Ductal @ samples @ $170 \mathrm{MPa}$ (calculated with fibres in the size fraction 0/2 mm).

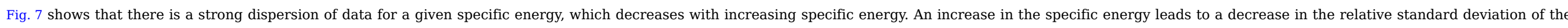

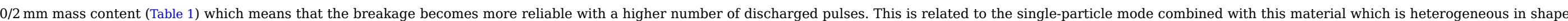
This variability should be decreased by using a continuous system as the PWTS

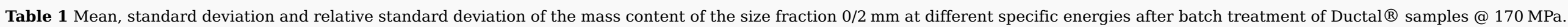

\begin{tabular}{|c|c|c|c|c|c|c|c|}
\hline Specific energy $(\mathrm{kWh} / \mathrm{t})$ & 1.2 & 7.2 & 15.0 & 18.8 & 27.0 & 34.7 & 59.9 \\
\hline 0/2 mm - Mean (\%) & 1.5 & 13.4 & 25.5 & 38.6 & 46.8 & 57.8 & 64.5 \\
\hline 0/2 mm - Standard deviation (\%) & 0.6 & 4.2 & 4.4 & 3.8 & 3.4 & 3.3 & 1.7 \\
\hline 0/2 mm - Relative standard deviation (\%) & 37.1 & 31.5 & 17.2 & 9.7 & 7.4 & 5.8 & 2.7 \\
\hline
\end{tabular}

\subsection{Results obtained with the PWTS operating at a continuous pilot scale}

\subsubsection{Repeatability of the PWTS treatment}

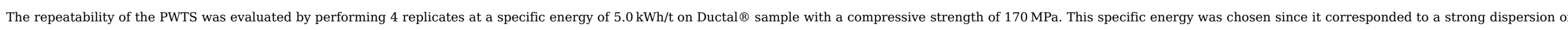

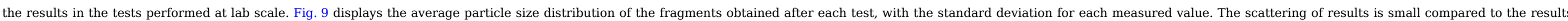

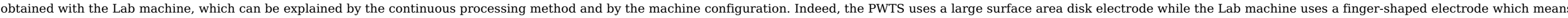

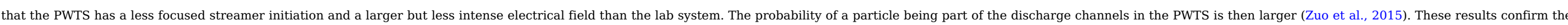
good repeatability of the EPF treatment with the PWTS.

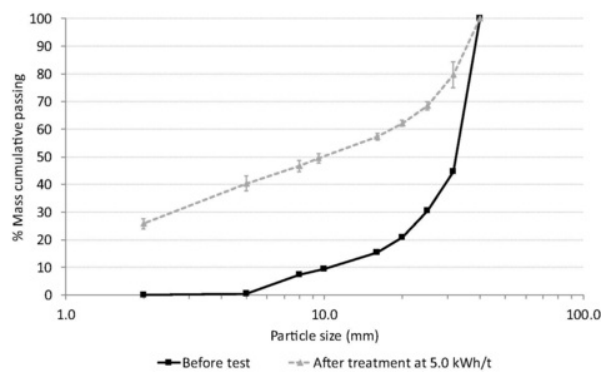

Fig. 9 Particle size distribution before and after an EPF continuous treatment (Is it possible to add (PWTS machine)?]at $5.0 \mathrm{kWh} / \mathrm{t}$ of Ductal@ samples @ $170 \mathrm{MPa}$

\subsubsection{Influence of the specific energy on the selective fragmentation of UHPFRC samples}




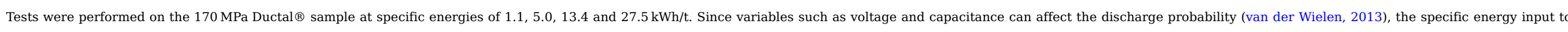

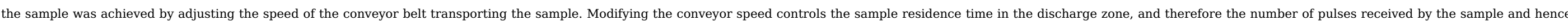

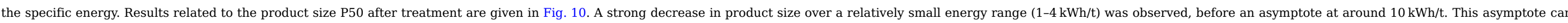

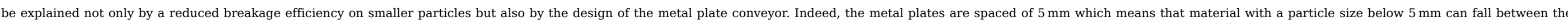

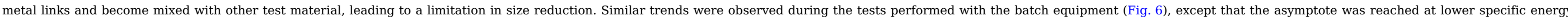

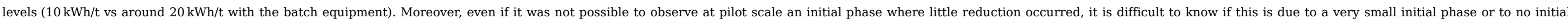
phase at pilot scale; it would have required more data at specific energies between 1 and $5 \mathrm{kWh} / \mathrm{t}$.

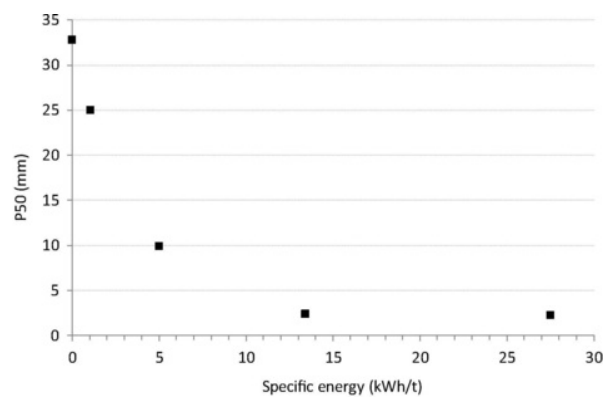

Fig. 10 P50 of the products after an EPF continuous treatment of Ductal $₫$ samples @ $170 \mathrm{MPa}$ as a function of the specific energy.

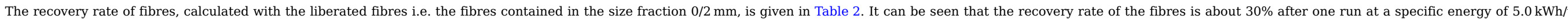

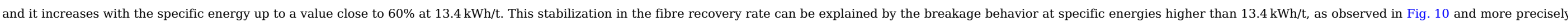

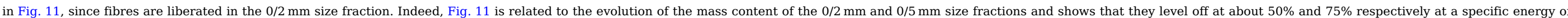

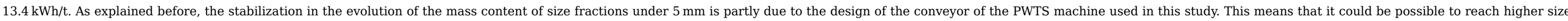

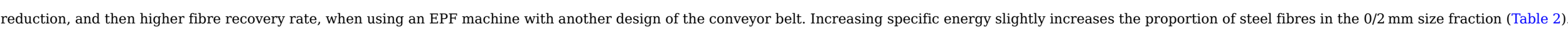

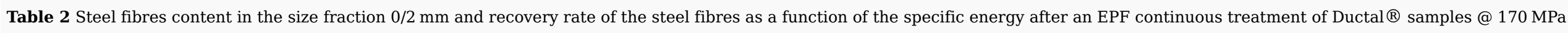

\begin{tabular}{|c|c|c|c|c|}
\hline & \multicolumn{4}{|c|}{ Specific energy $(\mathrm{kWh} / \mathrm{t})$} \\
\hline & 1.1 & 5. & 13.4 & 27.5 \\
\hline $\begin{array}{l}\text { Steel fibres content in the size fraction } 0 / 2 \mathrm{~mm} \\
\text { (\%mass) }\end{array}$ & 8.0 & 8.3 & 9.2 & 9.7 \\
\hline $\begin{array}{l}\text { Recovery rate of the steel fibres } \\
\text { (\%mass) }\end{array}$ & 11.3 & 26.6 & 53.3 & 57.6 \\
\hline
\end{tabular}

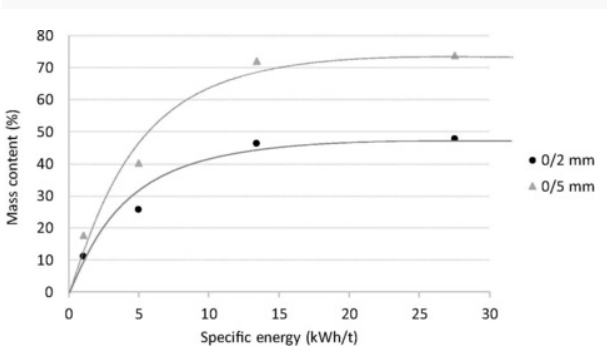

Fig. 11 Mass content of the size fractions $0 / 2 \mathrm{~mm}$ and $0 / 5 \mathrm{~mm}$ as a function of the specific energy after an EPF continuous treatment of Ductal@ samples @ $170 \mathrm{MPa}$ 


\subsubsection{Influence of the UHPFRC compressive strength}

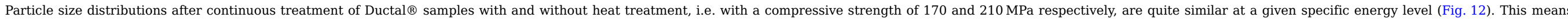

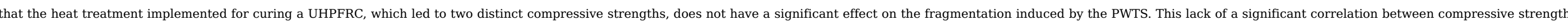

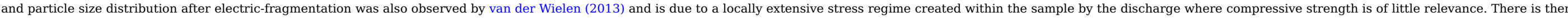
a limited extent of crushing around a plasma channel due to pressures locally exceeding the compressive strength of material (van der Wielen, 2013).

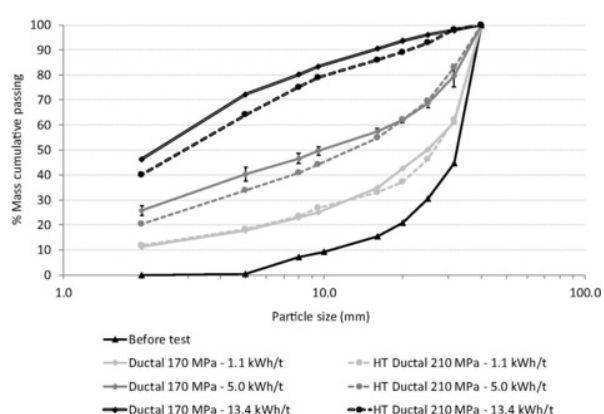

Fig. 12 Particle size distribution before and after an EPF continuous treatment performed at various specific energies for a Ductal@ sample @ 170 MPa (without heat treatment) and a Ductal@ sample @ 210 MPa (with heat treatment HT).

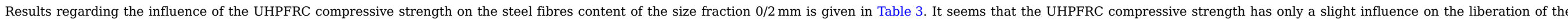

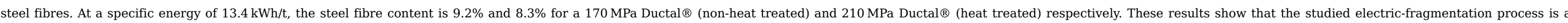
robust technical solution for the recycling of UHPFRC. This is very crucial for the implementation of this process since it could not be possible to sort all kind of UHPFRC waste.

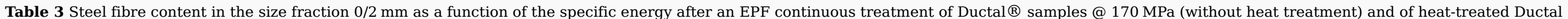
samples @ $210 \mathrm{MPa}$

\begin{tabular}{|c|c|c|c|c|}
\hline Specific energy (kWh/t) & 1.1 & 5.0 & 13.4 & 27.5 \\
\hline Ductal ${ }^{\circledR}$ sample @ $170 \mathrm{MPa}$ & 8.0 & 8.3 & 9.2 & 9.7 \\
\hline $\begin{array}{l}\text { Ductal }{ }^{\circledR} \text { sample @ } 210 \mathrm{MPa} \\
\text { (heat-treated) }\end{array}$ & 7.2 & 7.2 & 8.3 & \\
\hline
\end{tabular}

\section{Comparison of lab and continuous pilot-scale epf(It would be better to write it in capital letters "EPF") systems}

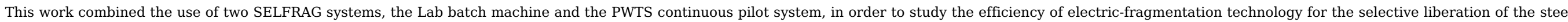

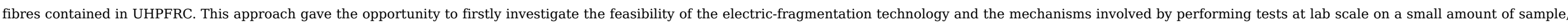
and secondly to study its up-scaling with the continuous machine at pilot scale.

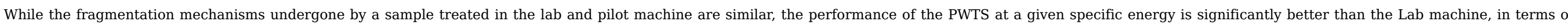

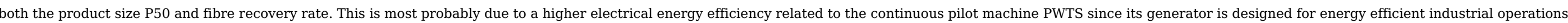

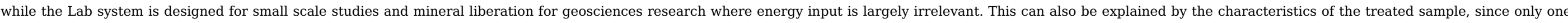

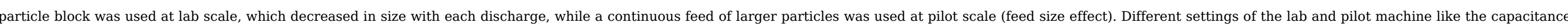
( $37.5 \mathrm{nF}$ in the Lab machine and $80 \mathrm{nF}$ in the PWTS) and pulse repetition rate ( $5 \mathrm{~Hz}$ in the Lab machine and $10 \mathrm{~Hz}$ in the PWTS) for example can also explain the observed differences.

\section{Conclusions}

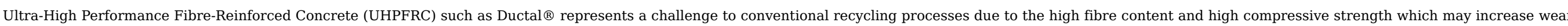




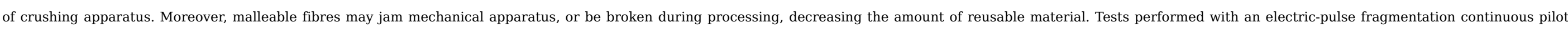

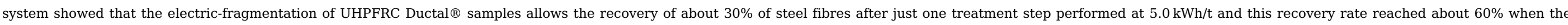

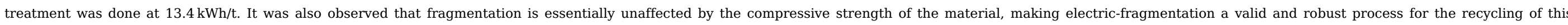

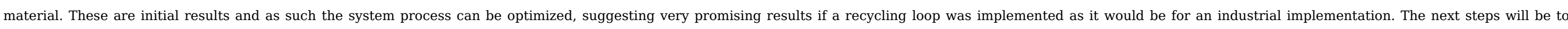

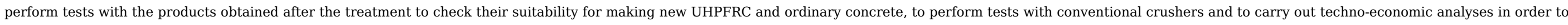
compare the two pathways.

\section{Uncited references}

NF P 18-470 (2016).

\section{Acknowledgements}

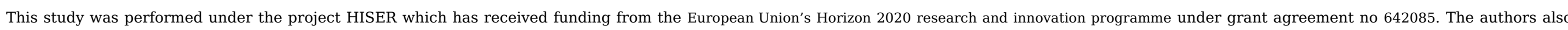
thank F. de Larrard for the fruitful discussions.

\section{References}

Afroughsabet V., Biolzi L. and Ozbakkaloglu T., High-performance fiber-reinforced concrete: a review, J. Mater. Sci. 51, 2016, 6517-6551.

Andres U., Jirestig J. and Timoshkin I., Liberation of minerals by high-voltage electrical pulses, Powder Technol. 104, 1999, 37-49.

Andres U., Timoshkin I., Jirestig J. and Stallknecht H., Liberation of valuable inclusions in ores and slags by electrical pulses, Powder Technol. 114, 2001 , 40-50.

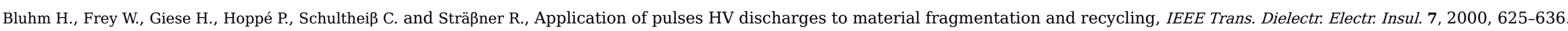

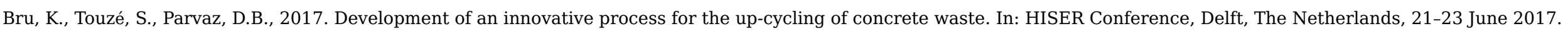

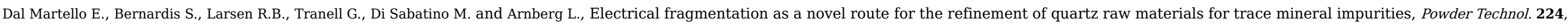
2012, 209-216.

HISER, Electrofragmentation technology and its benefits for construction and demolition waste, Newsletter 2016, 2.

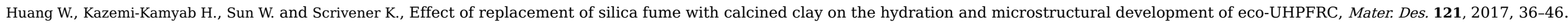

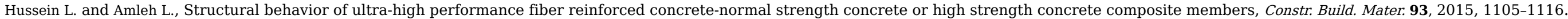

Iizasa S., Shigeishi M. and Namihira T., Recovery of high quality aggregate from concrete waste using pulsed power technology, Clean Technol. 2010, 325-328.

Inoue S., Iizasa S., Wang D., Namihira T., Shigeishi M., Ohtsu M. and Akiyama H., Concrete recycling by pulsed power discharge inside concrete, Int. J. Plasma Environ. Sci. Technol. 6, 2012, 183-188.

Kunieda M., Ueda N. and Nakamura H., Ability of recycling on fiber reinforced concrete, Constr. Build. Mater. 67, 2014, 315-320.

Máca P., Sovják R. and Vavřiník T., Experimental investigation of mechanical properties of UHPFRC, Procedia Eng. 65, 2013, 14-19.

Maten R.N., Ultra High Performance Concrete in Large Span Shell Structures, Master thesis, 2011, TUDelft.

NF P 18-470, Bétons fibrés Ultra Hautes Performances Spécification, performance, production et conformité, 2016, AFNOR French Standard Institute.

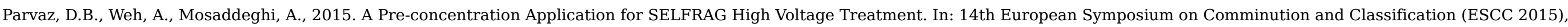

Chalmers University of Technology, Gothenburg, Sweden, 7-10 September 2015. 
Sedran T., Durand C. and de Larrard F., An Example of UHPFRC, In: Toutlemonde F. and Resplendino J., (Eds.), Designing and Building with UHPFRC 2011, John Wiley \& Sons.

Shi F., Zuo W. and Manlapig E., Characterisation of pre-weakening effect on ores by high voltage electrical pulses based on single-particle tests, Miner. Eng. 50-51, 2013 , 69-76.

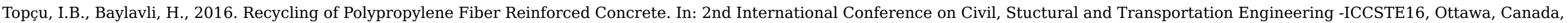
5-6 May 2016.

Touzé S., Bru K., Ménard Y., Weh A. and Von der Weid F., Electrical fragmentation applied to the recycling of concrete waste - effect on aggregate liberation, Int. J. Miner. Process. 158, 2017 , 68-75.

van der Wielen K.P., Pascoe R., Weh A., Wall F. and Rollinson G., The influence of equipment settings and rock properties on high voltage breakage, Miner. Eng. 46, 2013 , 100-111.

van der Wielen K.P., Application of High Voltage Breakage to a Range of Rock Types of Varying Physical Properties, Thesis Camborne School of Mine, 2013, University of Exeter.

Wang E., Shi F. and Manlapig E., Pre-weakening of mineral ores by high voltage pulses, Miner. Eng. 24, 2011, 455-462.

Wang E., Shi F. and Manlapig E., Mineral liberation by high voltage pulses and conventional comminution with same specific energy levels, Miner. Eng. 27, 2012a, 28-36.

Wang E., Shi F. and Manlapig E., Factors affecting electrical comminution performance, Miner. Eng. 34, 2012b, 48-54.

Yoo D. and Banthia N., Mechanical properties of ultra-high-performance fiber-reinforced concrete: a review, Cem. Concr. Compos. 73, 2016, 267-280.

Yoo D.-Y. and Yoon Y.-S., A review on structural behavior, design, and application of ultra-high-performance fiber-reinforced concrete, Int. J. Concr. Struct. Mater. 10, 2016 , 125-142.

Zuo W., Shi F., van der Wielen K.P. and Weh A., Ore particle breakage behaviour in a pilot scale high voltage pulse machine, Miner. Eng. 84, 2015, 64-73.

\section{Highlights}

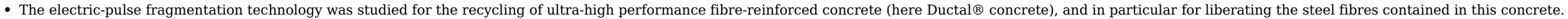

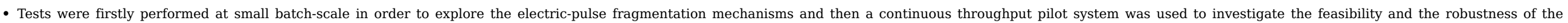
technology.

- With the pilot system, the recovery rates of the steel fibres were about $30 \%$ and $60 \%$ after just one treatment step performed at respectively $5.0 \mathrm{kWh} / \mathrm{t}$ and $13.4 \mathrm{kWh} / \mathrm{t}$.

\section{Queries and Answers}

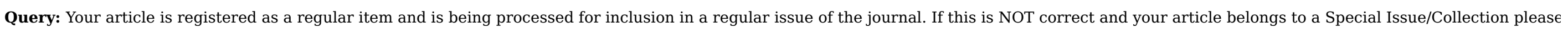
contact a.arulanandaraj@elsevier.com immediately prior to returning your corrections.

Answer: Yes

Query: The author names have been tagged as given names and surnames (surnames are highlighted in teal color). Please confirm if they have been identified correctly. Answer: Yes

Query: Highlights should only consist of 85 characters per bullet point, including spaces. The highlights provided are too long; please edit them to meet the requirement.

Answer: - Electric-pulse fragmentation was studied for recycling fibre-reinforced concrete.

- The electric-pulse fragmentation mechanisms were explored at small batch-scale.

- A continuous pilot system was used to assess the feasibility of the technology. 


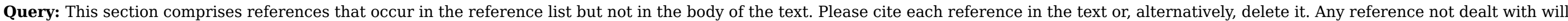
be retained in this section.

Answer: This reference was included in the text in the second sentence of the Introduction section (but removed by mistake when making the proof of the article).

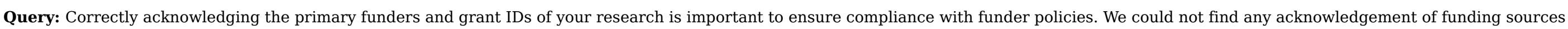
in your text. Is this correct? /

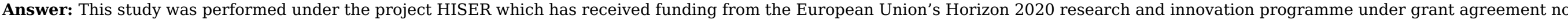
642085. The acknowledgment of this funding source is included in the Acknowledgments section. 